\title{
Investigation to Exoneration: A Systemic Review of Wrongful Conviction in Australia
}

\author{
Rachel Dioso-Villa, ${ }^{*}$ Roberta Julian, ${ }^{\dagger}$ Mark Kebbell, ${ }^{\ddagger}$ Lynne Weathered $\$$ \\ and Nina Westera**
}

\begin{abstract}
Wrongful conviction is an international problem that has attracted considerable research into identifying its prevalence, causes and correlates. Australia is not void of erroneous convictions; however, the international findings do not neatly apply to the Australian context. This article considers the wrongful conviction in Australia from a wide-angle perspective of investigation through to exoneration. It considers systemic issues related to the detection, correction and consequences of wrongful conviction, identifying how and why errors may occur at different stages of the criminal justice process. The article specifically covers the investigative process and issues related to the collection and processing of physical/forensic evidence and witness evidence, post-conviction issues in the identification and correction of wrongful convictions, and the consequences of wrongful conviction for exonerated individuals in Australia.
\end{abstract}

Keywords: wrongful conviction - exoneration - forensic evidence -

false confession - eyewitness identification - compensation

\section{Introduction}

Wrongful conviction is gaining increasing international attention. Estimates as to the frequency of wrongful convictions have been attempted in countries such as the United States ('US'), where a range of between 1 to 5 per cent of serious violent offences has been suggested (Gross 2013). However, it is generally agreed that it is an unknowable figure - it is not

* Senior Lecturer, School of Criminology and Criminal Justice, Griffith University, 176 Messines Ridge Road, Mt Gravatt Qld 4122 Australia. Email: r.diosovilla@griffith.edu.au.

† Associate Professor, Director, Tasmanian Institute of Law Enforcement Studies (TILES), University of Tasmania, Private Bag 22, Hobart 7001 Tas Australia. Email: roberta.julian@utas.edu.au.

‡ $\quad$ Professor, School of Applied Psychology, Griffith University, M24 Mt Gravatt Campus, Griffith University Qld 4111 Australia. Email: m.kebbell@griffith.edu.au.

§ Research Fellow, Griffith Criminology Institute, Griffith University, M10 Mt Gravatt Campus, Griffith University Qld 4111 Australia. Email: n.westera@griffith.edu.au.

** Director, Griffith University Innocence Project, Griffith Law School, Gold Coast Queensland 4222 Australia. Email: l.weathered@griffith.edu.au. 
something that can be tested within the entire prison population, as if it were a medical condition (Gross 2013).

It is only following an exoneration that the conviction becomes identified and classified as 'wrongful'. In a small percentage of cases (depending on the facts of the case) DNA testing will be sufficiently probative to uncover a wrongful conviction (and potentially identify the real perpetrator of the crime). However, the vast majority of post-conviction claims of wrongful conviction do not involve DNA or other scientific testing that reaches this high threshold or other types of fresh evidence of innocence to support the claim. As such, there are and will be many claims of wrongful conviction that remain just that.

Despite the unavailability of exact figures or percentages, it is clear that wrongful convictions occur. To date in the US, more than 1500 exonerees are officially listed on the National Registry of Exonerations. The Criminal Cases Review Commission in England has corrected more than 350 miscarriages of justice. Canada has rectified at least 18 wrongful convictions. Numerous wrongful convictions have occurred in Australia, with estimates of at least 71 individuals wrongly convicted between 1922 and 2015 (Dioso-Villa 2015).

Researchers have identified numerous systemic factors associated with wrongful conviction learned from unpacking cases of miscarriages of justice in different countries. Categories identified in the US include: eyewitness misidentification; false, misleading or improper forensic sciences; false confessions or admissions; official or government misconduct; informants or 'snitches'; bad lawyering; and perjury or false accusation (Garrett 2011; Gross and Shaffer 2012; Innocence Project 2013b). While further research is required before concluding that the same factors also apply in Australia, similar issues are mirrored in a number of Australian cases. For example, flawed forensic science was a major contributor to the wrongful convictions of Lindy and Michael Chamberlain (Supreme Court of the Northern Territory of Australia 1988) and Edward Splatt (Shannon 1984). False confessions were involved in the wrongful convictions of Kelvin Condren ( $R v$ Condren), John Button (Button $v$ The Queen), and Andrew Mallard (Mallard $v$ The Queen). Tunnel vision and the withholding of exculpatory evidence were additional factors in the Button and Mallard wrongful convictions, with official misconduct also highlighted in the Mallard case (Corruption and Crime Commission 2008).

This article examines the research on wrongful conviction in Australia from the start of the investigative process through to the individual's exoneration to map out where and how errors that may ultimately result in the conviction of an innocent person occur in the process. It also highlights the difficulty of detecting and correcting a wrongful conviction once it has occurred due to limitations of Australia's appellate processes. In doing so, some international comparisons are made as a way of considering the risk for error in Australia. Errors at different stages of the justice system can compound to lead to a wrongful conviction. Doyle (2010) offers a framework for understanding wrongful convictions not as anomalies in the criminal justice system, but as a result of systemic errors that can occur at various stages and by different actors in the system. He suggests that wrongful convictions could be understood as a systemic problem, rather than the result of discrete and independent events and errors. This article explores the application of this framework by identifying issues that can arise at the investigation, trial and appeals, and post-exoneration. Specifically, it: reviews the collection and processing of forensic and witness evidence; identifies difficulties within the court processes for overturning wrongful convictions; and discusses ongoing impact of wrongful conviction on exonerees. As such, it offers an overview of the state of wrongful conviction in Australia and a starting point for policy makers and academics to address and improve the detection, correction, treatment, redress and prevention of wrongful convictions. 


\section{The investigative process: Collecting and processing physical/forensic evidence}

Forensic science has played a prominent role in cases of wrongful conviction to exonerate those wrongly convicted through forensic DNA testing of evidence after conviction, and it is also a leading contributor to wrongful convictions through erroneous testing and misleading expert testimony (Garrett 2011; Gould et al 2013; Saks and Koehler 2005). In their study, Saks and Koehler (2005) identified forensic science errors as second only to eyewitness errors as leading factors associated with wrongful convictions (63 per cent and 71 per cent of cases, respectively). This is due, in part, to an uncritical 'faith' in the value of forensic evidence (Roach and Pease 2006). Police and the courts have routinely accepted the results of forensic science, rather than subjecting them to regular scrutiny and critique. In particular, judges ‘admit most forensic evidence' (Moriarty and Saks 2005:28) without question and lawyers are not necessarily equipped with the knowledge to critically engage with forensic science evidence in the courtroom (Edmond et al 2014). This lack of critical examination of forensic science provides an environment in which miscarriages of justice, based on problematic forensic science, are highly likely. The reviews of wrongful convictions bear this out (Garrett 2011; Gould et al 2013).

While considerable research has been undertaken in Australia on problems associated with the admissibility of forensic evidence in court (Edmond et al 2014; Edmond and San Roque 2014) and on the degree to which jurors do or do not understand DNA evidence (GoodmanDelahunty and Hewson 2010; Martire, Kemp and Newell 2013), recent research identifies problematic aspects of forensic science during the collection and processing stages (Julian et al 2011). This is further exacerbated by several factors, including that forensic science is a fragmented and specialised system (Roux, Crispino and Ribaux 2012), scientific approaches and methods are not well embedded in policing (Weisburd and Neyroud 2013), and there is clear evidence of breakdowns in communication between criminal justice agencies (Vincent 2010). Taken together, these factors can contribute to errors in the evaluation of forensic evidence; thus, caution must be exercised against over-reliance on forensic science.

\section{Taking physical evidence from the crime scene to court}

An Australian study (Julian et al 2011) on the effectiveness of forensic science in the criminal justice system has identified critical issues surrounding the integrity and value of forensic evidence at the crime scene, the forensic laboratory, the police, the coroner, and the courts. Errors can be generated at any of these stages and sites. First and foremost, errors can enter the system at the crime scene. Crime scene examiners vary considerably in their ability to collect traces that produce reliable forensic evidence. Recent reports in the United Kingdom (British Home Office 2007) and the US (National Academy of Sciences 2009) have 'highlighted that some examiners clearly outperform their peers in the quality of their work, with this difference resulting in more positive justice outcomes and less unsolved cases' (Kelty, Julian and Robertson 2011:175). If a crime scene is not processed effectively, the traces collected may not provide valuable information that could be used to direct an investigation and assist in solving the crime.

Errors may also occur at the forensic laboratory. Considerable attention has been given in the past to the potential occurrence of contamination in processing traces at forensic laboratories. As a consequence, forensic laboratories throughout Australia have developed complex quality assurance processes (Robertson, Kent and Wilson-Wilde 2013). More recently, problems of confirmation bias have been highlighted. Confirmation bias has been raised as a concern among forensic scientists engaged in pattern-matching (for example, DNA 
analysis, fingerprint analysis) (Dror, Charlton and Peron 2006) and is being addressed through Australian research (Tangen, Thompson and McCarthy 2011). Examples of improved practices include strategies to assist in controlling for the potential effects of bias in forensic laboratories (Found 2015) and the implementation of context management procedures in firearms departments (Stoel, Dror and Miller 2014).

Little is known about how detectives use forensic evidence in their investigations (Williams and Weetman 2013); however, it is unlikely that they incorporate forensic evidence as a routine component of criminal investigations when significant delays occur in receiving forensic reports due to unmanageable backlogs in police stations and laboratories (Strom and Hickman 2010). Under these conditions, forensic evidence cannot be used effectively to eliminate or identify suspects early in an investigation; rather, detectives will rely on more traditional processes of investigation in which forensic evidence is used to confirm, rather than identify, suspects (Strom and Hickman 2010), heightening the possibility of confirmation bias occurring under these circumstances.

As the forensic process moves into the courts, studies have also identified limited understanding of DNA evidence by lawyers, along with inadequate communication between forensic scientists and lawyers (Cashman and Henning 2012). The latter becomes particularly significant in light of recent studies identifying difficulties in the readability of forensic scientists' reports, which raises questions about how useful they are as sources of information for police and lawyers (Howes et al 2014).

\section{Physical evidence and wrongful conviction}

Ineffective or problematic use of forensic evidence in the processes leading to conviction, from criminal investigation through to its use in court, has the potential to influence the police investigation and the evidence obtained in the case, which may in turn contribute to wrongful convictions. Australian research highlights the necessity for criminal justice agencies and their personnel to have a high level of forensic awareness to enable them to harness the potential value of forensic evidence and, most importantly, to critically evaluate the use of forensic evidence in their everyday work practices.

In Australia, the 2009 wrongful conviction of Farah Jama $(R v$ Jama) for a rape he did not commit has led to a critical appraisal of the role of forensic evidence in criminal investigations and prompted a 'learning from error' approach to the Australian criminal justice system (Doyle 2010). In this case, the jury's verdict rested solely on DNA evidence, with no other corroborating evidence presented at the trial (Vincent 2010). The Vincent Report into this wrongful conviction detailed an extraordinary case of forensic evidence contamination (at a sexual assault crisis care unit rather than the laboratory) combined with limited interactions and information flow between the medical, scientific and law enforcement practitioners involved throughout the entirety of the case. Vincent found that the DNA evidence was perceived to possess 'an almost mystical infallibility that enabled its surroundings to be disregarded' (2010:11) and concluded that 'the Victorian criminal justice system had wholeheartedly let FJ [Farah Jama] down’ (Kelty et al 2013).

\section{The investigative process: Memory, eyewitness identification and false confessions}

Wrongful convictions are not only caused by erroneous or misleading forensic evidence; other factors either independently, or in combination, play a part. The most common cause is 
mistaken eyewitness identification (Scheck, Neufeld and Dwyer 2003). The fallibility of perception and memory of all people - both the investigator and the person providing information - makes errors possible (Nickerson 1998). Like the collection and preservation of physical/forensic evidence at a crime scene, care is needed to examine and preserve the accounts of witnesses and suspects.

An investigation involves gathering information from a variety of sources to establish if a criminal offence was committed and who was involved (Kebbell and Milne 1998). Eyewitnesses often provide this information and become the central leads in criminal investigations. They provide the police with information at multiple points across the course of the investigation, from a call-taker who initiates the police response, to frontline uniformed officers who are first to attend the scene, to detectives who conduct the investigation. Sometimes the witness will talk to the same police officer on multiple occasions to elicit an initial account and conduct formal interviews, write the brief for the evidence the witness is expected to give in court and, in some jurisdictions, prepare the witness to give that evidence. Similarly, an investigator is likely to gather information from sources other than one witness, including other witnesses, the crime scene, the suspect or other investigators. Each one of these varied interactions can generate errors that can contaminate the investigation (Wilcock, Bull and Milne 2008), as can the process of integrating the information obtained from all these sources to decide on further lines of enquiry, the identity of the alleged offender, or whether to proceed with a prosecution.

The first place an error can enter the system is a witness's memory for the event. Psychological research demonstrates memory is not like a video-recording (Tulving 1974; Suddendorf and Corballis 2008). We do not passively take in information and replay it; rather, memory is an active, creative process that can be inaccurate for a variety of reasons. Hence, witnesses may unwittingly integrate prior experiences (for example, media reports they have read, conversations they have had with other witnesses or associates: French, Garry, and Mori 2008; Gabbert, Memon and Wright 2006) and expectations into their accounts of what happened, even before police become involved (Greenberg, Westcott, and Bailey 1998). Such problems with the reliability of memory are exacerbated if the alleged crime occurred a long time ago (Read and Connolly 2007).

Errors can also occur with how an investigator perceives and remembers information obtained from that witness or other sources. Confirmation bias may occur when an investigator is motivated towards a particular outcome (Kassin, Dror and Kukucka 2013). For example, an investigator may be more likely to remember the information given by a witness that matches the description of a person the investigator already suspects of committing the offence; or the investigator may interview the witness in a suggestive way to elicit information to support his or her theory through leading questions and witnesses may inadvertently comply with these expectations (Loftus and Palmer 1974). The culmination of small (or not so small) errors like this may lead to a wrongful conviction.

\section{Investigative procedures and eyewitness interviews}

Despite the potential for error, investigators do not often document their decision making, which means we know little about the investigative process. We know the most about homicides, because they tend to be better documented (Brodeur 2010). We know little about wrongful convictions other than more readily detectable DNA exonerations (particularly in homicide and rape), which make it obvious that any identification of the offender or confession must have been false (Gross 2013). Our knowledge about wrongful convictions is therefore restricted by the information that is available about the investigative process. 
Throughout the process an investigator decides what lines of enquiry to follow, yet this entire process is only selectively documented (Brodeur 2010). Similarly, how investigators record adult witness interviews can be problematic. The usual method is for an investigator to record these interviews on a written statement - an unreliable process prone to bias because it relies on an investigator reproducing from memory what the witness says (Köhnken, Thürer and Zoberbier 1994). In an attempt to control the flow of information to make this task manageable, investigators often resort to leading questioning methods that can result in less reliable witness information (Westera, Kebbell and Milne 2011). The statement usually contains no record of the questions asked, preventing criminal justice professionals from scrutinising any problems with the interview process.

False identifications are a particularly common cause of wrongful convictions (Scheck, Neufeld and Dwyer 2003). Research supports four rules developed to minimise the likelihood of a wrongful conviction resulting from the misidentification of a suspect from a line-up (Wells et al 1998). The first is that the person administering the line-up should not know which member of the line-up is the suspect. The second is that the eyewitness should be warned that the criminal might not be present in the line-up, so the witness is not compelled to select the person who most resembles the offender. The third is that all foils, members of the line-up, should be selected based on the eyewitness's verbal description of the criminal and all foils should be similar to each another and the suspect should not stand out. The fourth is that confidence should be recorded at the time of identification, and any increases in confidence should be treated with caution since witnesses' accounts may be affected by additional information heard or learned about the crime or suspect (for instance the suspect's criminal history of similar offences). Violating these four rules has been associated with misidentifications in the US (Wells et al 1998), and there is a strong evidence base that indicates that complying with these rules reduces misidentifications. Nevertheless, these rules are not exhaustive and additional procedures, such as sequential presentation of line-up members and video-recording the procedure, can be adopted (for further details, see US Department of Justice 1999).

Currently there is no universal legislation in Australia regulating how identifications are conducted. The closest thing to a national code for identifications is the Evidence Act 1995 (Cth) s 114, although it is not adopted nationwide. This legislation meets three of Wells et al's (1998) rules: the witness is told the offender may not be present; it is not communicated to witnesses who the suspect is; and the suspect and foils are of similar description. The witness's confidence in his or her determination is not recorded unless the witness volunteers a statement. In Queensland, identification evidence is covered in the Police Powers and Responsibilities Act 2000 (Qld). This Act only meets two of the rules for accurate identifications: there is no requirement for confidence to be recorded or for the witness to be warned that the suspect may not be present. Further, while the Uniform Evidence Law states that identifications should be done with an identification parade of the sequential presentation of a line-up of members, in practice, it appears photo-boards are used in the simultaneous presentation of line-up members. This illustrates the possible disconnect between police practice and legislation.

\section{Protecting against false confessions}

False confessions are also a frequent factor in wrongful convictions. For example, Kassin et al (2010) suggest that DNA exonerations indicate that 15-20 per cent of wrongful convictions in the US involved false confessions (usually with other factors such as eyewitness error). However, generalising from the US to Australia requires caution. In the US, the use of an arguably coercive interview strategy, the 'Reid Technique' (Inbau et al 2001), appears 
frequent and it may facilitate a greater number of false confessions than typical suspect interviewing in Australia. Kassin and Gudjonsson (2004) argue that the Reid Technique has three stages: 'custody and isolation' - where the suspect is detained, isolated and resistance is weakened; 'confrontation' - where the suspect is confronted with incriminating evidence that may include fabricated evidence, denials are rejected as out of hand, and consequences of denials are emphasised; and 'minimisation' - where the interviewer makes the crime seem less serious and provides face-saving reasons for the crime, which may include suggestions that the victim deserved it. Given these coercive strategies, it is not surprising that false confessions occur. However, the combination of legislation and a cultural tradition of following policing in England and Wales mean that the interviewing of suspects appears to be different in Australia. In particular, legislation requires interviews with suspects to be recorded in most instances, ensuring the process is transparent, and the suspect is cautioned by the police that he or she does not have to say anything and may talk to a lawyer (for example, s 281 of the Criminal Procedure Act 1986 (NSW)).

In recent times, most police services in Australia have started to use an approach to interviewing common in England and Wales called the PEACE approach (Preparation and Planning, Engage and Explain, Account and Clarification, Closure and Evaluation: Clarke and Milne 2001). This approach emphasises fairness and explicitly rejects coercion; it encourages interviewers to find out the 'truth' and to allow the suspect to give his or her own account. Police in Australia are not permitted to fabricate or lie to suspects in a suspect interview and, importantly, adherence to the PEACE protocol and the relevant legislation is ensured through the requirement to record all suspect interviews where practicable. For these reasons, confessions where the police have coerced responses from suspects would be less likely than in the US.

Nevertheless, the safeguards in place to prevent coerced confessions do not eliminate the possibility entirely. Some people confess to crimes without any coercion; these are voluntary false confessions (Gudjonsson 2003). In these cases, the individual may believe they have committed a crime (for example, because of a mental illness such as schizophrenia or because of a desire achieve notoriety). Further, while legislation is intended to prevent false confessions, it is not effective if it is not complied with. There have been cases where the courts have not accepted admissions because they were not legally elicited, for example, because of denying legal advice (Arthurs $v$ Western Australia) or not providing a translator (State of Western Australia $v$ Gibson). Situations concerning false confessions are of particular concern as confession evidence has a profound impact on juries' decision-making, even when they know it is tainted by coercive police interviewing (Kassin and Sukel 1997).

Investigative errors, such as false confessions and identifications, are compounded if investigators are naive to their occurrence or are motivated to ignore them. However, once errors in the investigation process move to the prosecution phase they are likely to be more difficult to identify because other decision-makers in the prosecution process (lawyers, judges, jurors) often can rely on only the police's secondhand interpretation of the evidence. The investigator generates the brief evidence that forms the basis of the prosecution case and disclosure to defence counsel. Even if defence counsel is cognisant of potential errors and has the resources to conduct further enquires, the damage done to memory may be irreversible. Unless there is contradictory evidence from other sources, there is no reliable way of discerning correct from erroneous accounts, including false confessions (Read and Connolly 2007). Video recording witness interviews instead of producing a written statement and documenting the decision-making of investigators can reduce the risk of these errors occurring. However, memory decays over time, which limits the opportunity for decisionmakers to access additional information from what investigators have gathered and reported. 


\section{Post-conviction: Limitations on the correction of wrongful conviction in Australia}

Ensuring that investigative practices conform to best practice is critical in addressing the problem of wrongful conviction, in part because identifying and correcting wrongful convictions is fraught with difficulties. Problems encountered in the identification and correction of wrongful convictions within the Australian legal system have been discussed elsewhere (Hamer 2014; Sangha and Moles 2014; Weathered 2005). For the purpose of this article, key aspects are briefly summarised below.

\section{Limited appeal avenues}

Following a trial there is a general restriction to only one appeal, which occurs at the State appellate level (see Grierson $v R ; R v N u d d$ ). This appeal must typically be launched within one month of the conviction and relies on arguments relevant to the evidence presented at trial. New or fresh evidence of innocence is rarely available so soon after trial and a wrongfully convicted person in Australia spends an average of 4.5 years in prison before release, making this a near impossibility of exoneration within one month of conviction (Dioso-Villa 2012). If leave is granted, the High Court of Australia may offer a further appeal for a small percentage of criminal cases. However, the current interpretation of the High Court's ambit is that it is constitutionally restricted from hearing fresh evidence, so that even if fresh and compelling new evidence of innocence became available, it would be unable to take that into account in its decision-making (Mickelberg $v$ The Queen; Re Sinanovic's Application).

The Statutes Amendment (Appeals) Act 2013 (SA) and the Crimes Appeal and Review Act 2001 (NSW) may offer state-level post-appeal avenue, but these too are limited in their ability to correct wrongful convictions (Hamer 2014). Elsewhere in Australia, wrongfully convicted people are still reliant on petitioning for a pardon from the Executive, such as the Attorney General, as the only way forward. However, the lack of transparency surrounding the process and decision of the Executive to refer or not to refer a case may result in the perception that petitions are dismissed without the full and impartial consideration that might otherwise be given if applications were received directly by the courts or by an independent body of review, such as the Criminal Cases Review Commission in England.

\section{Investigative difficulties}

Claims of innocence are easily dismissed if they are without supporting evidence. The key to success with any of the legal avenues above may be the availability of new or fresh evidence that undermines the safety of the original conviction. Ascertaining new or fresh evidence of innocence is, however, hindered by the lack of post-appeal investigatory powers. As the Law Council of Australia commented:

The Executive Government makes a decision on whether to refer a matter to the appeal court based on the material submitted by the petitioner, that is, the convicted person. The Executive rarely conducts its own inquiry...

The result is that post-conviction the entire burden, including the financial burden, of identifying, locating, obtaining and analysing further evidence rests entirely with the convicted person. He or she has no particular power or authority to compel the production of information, interview witnesses or conduct scientific testing on relevant materials (Law Council of Australia 2012:12). 
With no power or authority to compel the production of information, interview witnesses or conduct scientific testing on relevant materials, applicants (or those working on their behalf) are thwarted in their attempts to access full information and potentially exculpatory evidence. The South Australian Legislative Review Committee highlighted a similar point in relation to scientific evidence and recommended that a Forensic Review Panel be established to 'enable the testing or re-testing of forensic evidence which may cast reasonable doubt on the guilt of a convicted person' (Legislative Review Committee 2012:84)

Perhaps the most powerful scientific tool currently available to the criminal justice system is DNA evidence. While it is only relevant in a small percentage of cases, DNA innocence testing can uncover wrongful convictions and assist with identifying the true perpetrators of the crimes. To date, almost 50 per cent of the 314 DNA exonerations in the US have also resulted in the identification of the true suspect or perpetrator (Innocence Project 2013a). All 50 US States now have legislative schemes to enable DNA innocence testing. Only New South Wales, via ss 96 and 97 of the Crimes (Appeal and Review) Act 2001 (NSW), and Queensland via the Guidelines for Applications to the Attorney-General to Request Postconviction DNA Testing offer some legal structure for post-conviction DNA testing in Australia, and these are limited in their application (Weathered 2013).

\section{International obligations and options for Australia}

The Australian Human Rights Commission, among others, has expressed concern that the current system does not provide an adequate process for the review of wrongful conviction claims and consequently may not meet international obligations under act 14 of the International Covenant on Civil and Political Rights (Australian Human Rights Commission 2011; Sangha and Moles 2014). Other countries have introduced substantial new measures to investigate claims of wrongful conviction. The Criminal Cases Review Commission ('CCRC') was first established in Birmingham with jurisdiction over England, Wales and Northern Ireland. Similar bodies were subsequently created in Norway and Scotland. Canada established a Criminal Conviction Review Group to expand upon and make more transparent the mercy provisions previously applying to claims of wrongful conviction - the previous provisions were similar to those that still apply in Australia.

Internationally, the CCRC is considered the most comprehensive measure employed in addressing wrongful conviction because of its independence, funding, extensive investigative powers, and powers of referral to appellate courts (Roach 2012; Weathered 2012). The potential establishment of a CCRC in Australia was first raised in 2003 within the Australian Law Reform Commission's Inquiry into the Protection of Human Genetic Information in Australia (Australian Law Reform Commission 2003). The need for a CCRC at either the national or state level has been debated since that time, with strong support from a number of bodies, including the Law Council of Australia and the Australian Human Rights Commission, but it has to date been rejected. The Legislative Review Committee in South Australia specifically considered whether a CCRC should be established for that state. It determined, however, that the size of South Australia did not justify the resources required for such a body (Legislative Review Committee 2012:81). It further noted jurisdictional difficulties that may arise if such a body was created at a national level (Legislative Review Committee 2012:81). Without mechanisms that increase post-conviction investigatory powers and allow for increased appellate access, many cases of innocence will simply be left untested and these individuals will remain incarcerated. 


\section{Post-exoneration: Consequences of wrongful conviction}

Innocence adds an unparalleled dimension of difficulty for exonerees during their incarceration, and after their release it makes their experience unique from ex-offenders and guilty prisoners. For example, exonerees tend to serve longer sentences in prison than other inmates, since they do not participate in rehabilitation and treatment programs that require them to admit guilt or demonstrate remorse (Campbell and Denov 2004). They are ineligible for re-entry services designed to assist parolees with work placements, accommodation in halfway houses, and access to community services (Grounds 2004). They are responsible for expunging their criminal records, as this is not done automatically and is essential for obtaining long-term employment and housing. They may also experience the consequences of unwanted notoriety for either the crime for which they were falsely convicted or their subsequent exoneration.

Exonerees may seek redress for wrongful conviction by filing civil claims against police officers, legal counsel or other state officials they believe to be responsible for their wrongful convictions, though it is difficult to prove that parties acted with malice or the ill intent that is required for a successful tortious claim (Sheehy 1999). They may seek compensation through the state legislature, which outlines the specific monetary award paid to the exoneree (Hoel 2008), though this is rarely pursued in Australia (Dioso-Villa 2012). Exonerees may be eligible to apply for ex gratia payments awarded by the state. Given that there are no guidelines or criteria to award payments, however, ex gratia payments are not automatically awarded for wrongful conviction. Rather, they are typically awarded if there is demonstrable injury or loss experienced as a result of the wrongful conviction, evidence of gross state misconduct, or the case received a lot media attention (Dioso-Villa 2012).

Because of the lack of financial resources to pursue civil suits, the rarity of political connections to draft and lobby a specialised Bill and the discretionary nature of ex gratia awards, Australia lacks any meaningful form of legislated redress for wrongful conviction (Dioso-Villa 2014). Currently, with the exception of the Australia Capital Territory ('ACT'), there is no law or statutory right to compensate for wrongful conviction and wrongful imprisonment (Human Rights Act 2004 (ACT)). Other countries, such as the US, have compensation legislation that primarily provides monetary payments for wrongful conviction and incarceration and some states provide additional support for lost wages, child support and legal fees incurred (Innocence Project 2010).

Federal compensation legislation in Australia can be designed to address the economic and non-economic loss experienced by exonerees (Armbrust 2004; Lonergan 2008). This could accommodate individual re-entry needs, including tuition deductions or state assistance to complete high school and college diplomas, access to skills training and work placements, and assistance to find affordable housing. Such a comprehensive and individualised approach could utilise Australia's existing infrastructure of specialised problem-solving courts, such as those in place for domestic violence, drug offenses and mental health offenders (Freiberg 2002). Simply put, if exonerees could access these resources upon release from prison, this individualised delivery of services could ensure that state resources are used effectively and would give exonerees the best chance at their successful re-entry into society. Any amendments to the current situation, through state or federal legislation, that address monetary compensation or services would place Australia on par with other countries in their postexoneration treatment of the wrongfully convicted. 


\section{Conclusion}

The systemic analysis presented in this article identified possible errors that can lead to a wrongful conviction and the pitfalls that can hinder its correction once errors are identified. At each stage, from investigation to exoneration, Australia is in a position to evaluate and address wrongful conviction through the detection and treatment of existing cases, redress for exonerees, and the prevention of future cases. However, there is no easy solution to address issues of wrongful conviction in Australia, nor are there for its prevention and treatment. Errors in evidence collection at the investigation stage affects what is presented as evidence at trial, which in turn affects the case verdict that can lead to an erroneous conviction. Once a conviction is established, given the legal constraints with the Australian appellate process, it is very difficult for the courts to overturn the decision. Additional issues arise after wrongfully convicted individuals are released from prison, since they receive little to no government assistance to help with their successful re-entry into the community.

This article is designed to start the discussion between academics, practitioners and lawmakers regarding wrongful conviction as a systemic issue that warrants a comprehensive systemic solution, rather than a rare or accidental occurrence. Rather than anomalies in the system, wrongful convictions can be regarded as rare opportunities to dissect how errors occur and compound at different stages of the criminal justice system that leads to systemic breakdown with the hope of detecting, correcting and preventing future occurrences. 


\section{Cases}

Arthurs v State of Western Australia [2007] WASC 2009 (31 August 2007)

Button $v$ The Queen [2002] WASCA 35 (25 January 2002)

Grierson v R (1938) 60 CLR 431

Mallard v The Queen (2005) 224 CLR 125

Mickelberg v The Queen [2004] WASCA 145 (2 July 2004)

R v Condren; Ex parte Attorney General of Queensland [1991] 1 Qd R 574 (26 June 1990)

$R$ v Jama (Unreported, Supreme Court of Victoria, Court of Appeal, 2009)

$R v$ Nudd [2007] QCA 40 (15 February 2007)

Re Sinanovic's Application [2001] HCA 40 (11 July 2001)

State of Western Australia v Gibson [2014] WASC 240 (4 July 2014)

\section{Legislation}

Crimes (Appeal and Review) Act 2001 (NSW)

Human Rights Act 2004 (ACT)

Statutes Amendment (Appeals) Act 2013 (SA)

Supreme Court of the Northern Territory of Australia (1988) Reference under s 433A of the Criminal Code by the Attorney-General for the Northern Territory of Australia of Convictions of Alice Lynne Chamberlain and Michael Leigh Chamberlain: NTSC 64 (15 September 1988)

\section{References}

Armbrust S (2004) 'When Money Isn’t Enough: The Case for Holistic Compensation of the Wrongfully Convicted', American Criminal Law Review 41, 157-82

Australian Human Rights Commission (2011) Inquiry into the Criminal Cases Review Commission Bill 2010, Sydney, Australia

Australian Law Reform Commission (2003) Essentially Yours: The Protection of Human Genetic Information in Australia

British Home Office (2007) ‘Summary Report of the Scientific Work Improvement (SWIM) Package’, British Home Office

Brodeur J (2010) The Policing Web, Oxford University Press

Campbell K and Denov M (2004) 'The Burden of Innocence: Coping with a Wrongful Imprisonment', Canadian Journal of Criminology and Criminal Justice 46, 139-63

Cashman K and Henning T (2012) 'Lawyers and DNA: Issues in Understanding and Challenging the Evidence’, Current Issues in Criminal Justice 24(1), 69-83 
Clarke C and Milne R (2001) A National Evaluation of the PEACE Investigative Interviewing Course, Home Office, London

Corruption and Crime Commission (2008) 'Report on the Inquiry into Alleged Misconduct by Public Officers in Connection with the Investigation of the Murder of Mrs Pamela Lawrence, the Prosecution and Appeals of Mr Andrew Mark Mallard, and Other Related Matters', Perth, Western Australia

Dioso-Villa R (2012) 'Without Legal Obligation: Compensating the Wrongfully Convicted in Australia', Albany Law Review 75(3), 101-44

Dioso-Villa R (2014) “'Out of Grace”: Inequity in Post Exoneration Remedies for Wrongful Conviction', University of New South Wales Law Journal 37(1), 349-75

Dioso-Villa R (2015) 'A Repository of Wrongful Convictions in Australia: First Steps Toward Estimating Prevalence and Causal Contributing Factors’, Flinders Law Journal 17, 163-202

Doyle JM (2010) 'Learning from Error in American Criminal Justice', Journal of Criminal Law and Criminology 100(1), 109-48

Dror IE, Charlton D and Peron AE (2006) 'Contextual Information Renders Experts Vulnerable to Making Erroneous Identifications’, Forensic Science International 156, 74-8

Edmond G, Martire K, Kemp R, Hamer D, Hibbert B, Ligertwood A, Porter G, San Roque M, Searston R, Tangen J, Thompson M and White D (2014) 'How to Cross-examine Forensic Scientists: A Guide for Lawyers', Australian Bar Review 39, 174-97

Edmond G and San Roque M (2014) 'Before the High Court. Honeysett $v$ The Queen: Forensic Science, “Specialised Knowledge” and the Uniform Evidence Law', Sydney Law Review 36, 323-44

Found B (2015) 'Deciphering the Human Condition: The Rise of Cognitive Forensics', Australian Journal of Forensic Sciences 47(4), 386-401

Freiberg A (2002) 'Therapeutic Jurisprudence in Australia: Paradigm Shift or Pragmatic Incrementalism', Law in Context 20(2), 6-23

French L, Garry M and Mori K (2008) 'You Say Tomato? Collaborative Remembering Leads to More False Memories for Intimate Couples than for Strangers', Memory 16(3), 262-73

Gabbert F, Memon A and Wright DB (2006) 'Memory Conformity: Disentangling the Steps toward Influence during a Discussion’, Psychonomic Bulletin and Review 13(3), 480-5

Garrett BL (2011) Convicting the Innocent: Where Criminal Prosecutions Go Wrong, Harvard University Press

Goodman-Delahunty J and Hewson L (2010) 'Improving Jury Understanding and Use of Expert DNA Evidence’, Technical and Background Paper No 37, Australian Institute of Criminology

Gould JB, Carrano J, Leo RA and Young J (2013) 'Predicting Erroneous Convictions: A Social Science Approach to Miscarriages of Justice’, Research report, US Department of Justice

Greenberg MS, Westcott DR and Bailey SE (1998) 'When Believing is Seeing: The Effect of Scripts on Eyewitness Memory', Law and Human Behavior 22(6), 685-94

Gross SR (2013) ‘How Many False Convictions are There? How Many Exonerations are There?’ in CR Huff and M Killias (eds), Wrongful Convictions and Miscarriages of Justice: Causes and Remedies in North American and European Criminal Justice Systems, Routledge, 45-60 
Gross SR, Jacoby K, Matheson DJ, Montgomery N and Patil S (2005) 'Exonerations in the United States 1989 through 2003', Journal of Criminal Law and Criminology 95(2), 523-60

Gross SR and Shaffer M (2012) 'Exonerations in the United States: 1989-2012, A Report by the National Registry of Exonerations', National Registry of Exonerations

Grounds A (2004) 'Psychological Consequences of Wrongful Conviction and Imprisonment', Canadian Journal of Criminology and Criminal Justice 46, 165-82

Gudjonsson GH (2003) The Psychology of Interrogations and Confessions: A Handbook, Wiley

Hamer D (2014) 'Wrongful Convictions, Appeals, and the Finality Principle: The Need for a Criminal Cases Review Commission', University of New South Wales Law Journal 37, 270-311

Hoel A (2008) ‘Compensation for Wrongful Conviction', Trends and Issues in Crime and Criminal Justice, Australian Government and Australian Institute of Criminology

Howes L, Julian R, Kelty SF, Kemp N and Kirkbride KP (2014) 'The Readability of Expert Reports for Nonscientist Report-users: Reports of DNA Analysis’, Forensic Science International 237, 7-18

Inbau F, Reid J, Buckley J and Jayne B (2001) Criminal Interrogation and Confessions, Aspen

Innocence Project (2010) 'Making Up for Lost Time: What the Wrongfully Convicted Endure and How to Provide Fair Compensation’, Benjamin N Cardoza School of Law, Yeshiva University

Innocence Project (2013a) 'Factsheet: DNA Exonerations Nationwide Innocence Project’ (on file with author)

Innocence Project (2013b) 'Understanding Crime Victim Perspectives on Wrongful Convictions', 29 July $2013<$ http://www.innocenceproject.org/understand/>

Julian R, Kelty SF, Roux C, Woodman P, Robertson J, Davey A, Hayes R, Margot P, Ross A, Sibly H and White R (2011) 'What is the Value of Forensic Science? An Overview of the Effectiveness of Forensic Science in the Australian Criminal Justice System Project', Australian Journal of Forensic Sciences 43(4), $217-29$

Kassin SM, Drizin S, Grisso T, Gudjonsson G, Gisli H, Leo R and Redlich A (2010) 'Police-induced Confessions: Risk Factors and Recommendations', Law and Human Behavior 34, 3-38

Kassin SM, Dror IE and Kukucka J (2013) 'The Forensic Confirmation Bias: Problems, Perspectives, and Proposed Solutions', Journal of Applied Research in Memory and Cognition 2(1), 42-52

Kassin SM and Gudjonsson GH (2004) 'The Psychology of Confessions: A Review of the Literature and Issues', American Psychological Society 5(2), 33-67

Kassin SM and Sukel H (1997) 'Coerced Confessions and the Jury: An Experimental Test of the "Harmless Error” Rule', Law and Human Behavior 21, 27-46

Kebbell MR and Milne R (1998) 'Police Officers' Perceptions of Eyewitness Performance in Forensic Investigations', The Journal of Social Psychology 138(3), 323-30

Kelty SF, Julian R and Robertson J (2011) 'Professionalism in Crime Scene Examination: The Seven Key Attributes of Top Crime Scene Examiners', Forensic Science Policy and Management: An International Journal 2(4), 175-86

Köhnken G, Thürer C and Zoberbier D (1994) 'The Cognitive Interview: Are the Interviewers' Memories Enhanced, Too?’, Applied Cognitive Psychology 8(1), 13-24 
Law Council of Australia (2012) Policy Statement on a Commonwealth Criminal Cases Review Commission, 21 April 2012 <https://www.lawcouncil.asn.au/lawcouncil/images/LCA-PDF/docs-dated/20120421 ApprovedLCAPolicyStatementonCthCriminalCasesReviewCommission.pdf>

Legislative Review Committee (2012) 'Report of the Legislative Review Committee on its Inquiry into the Criminal Cases Review Commission Bill 2010’

Loftus E and Palmer JC (1974) 'Reconstruction of Automobile Destruction: An Example of the Interaction between Language and Memory', Journal of Verbal Learning and Verbal Behavior 13(5), 585-9

Lonergan JR (2008) 'Protecting the Innocent: A Model for Comprehensive, Individualized Compensation of the Exonerated', Legislation and Public Policy 11, 405-52

Martire KA, Kemp RI and Newell BR (2013) 'The Psychology of Interpreting Expert Evaluative Opinions', Australian Journal of Forensic Sciences 45, 305-14

Moriarty JC and Saks MJ (2005) 'Forensic Science: Grand Goals, Tragic Flaws, and Judicial Gatekeeping’, Judges' Journal 44(5), 16-33

National Academy of Sciences (2009) Strengthening Forensic Science in the United States, National Academy of Sciences

Nickerson RS (1998) 'Confirmation Bias: A Ubiquitous Phenomenon in Many Guises', Review of General Psychology 2(2), 175-220

Read JD and Connolly A (2007) 'The Effects of Delay on Long-term Memory for Witnessed Events' in MP Toglia, JD Read, DR Ross and RCL Lindsay (eds), Handbook of Eyewitness Psychology: Volume I Memory for Events, Lawrence Erlbaum Associates, 117-55

Roach J and Pease K (2006) 'DNA Evidence and Police Investigations: A Health Warning', Police Professional 52, 1-9

Roach K (2012) 'Independent Commission to Review Claims of Wrongful Convictions: Lessons from North Carolina’, Criminal Law Quarterly 58, 283-90

Robertson J, Kent K and Wilson-Wilde L (2013) 'The Development of a Core Forensic Science Standards Fraemwork for Australia', Forensic Science Policy and Management: An International Journal 4(3-4), 59-67

Roux C, Crispino F and Ribaux O (2012) 'From Forensics to Forensic Science', Current Issues in Criminal Justice 24(1), 7-24

Saks MJ and Koehler JJ (2005) ‘The Coming Paradigm Shift in Forensic Identification Science’, Science 309, 892-5

Sangha B and Moles R (2014) ‘MacCormick’s Theory of Law, Miscarriages of Justice and the Statutory Basis for Appeals in Australian Criminal Cases', University of New South Wales Law Journal 37, 243-69

Scheck B, Neufeld P and Dwyer J (2003) Actual Innocence: When Justice Goes Wrong and How to Make it Right, New American Library

Shannon CR (1984) 'Royal Commission of Inquiry in Respect to the Case of Edward Charles Splatt', Adelaide, South Australia

Sheehy CE (1999) 'Compensation for the Wrongful Conviction in New Zealand', Auckland University Law Review 8, 976-1000

Stoel RD, Dror IE and Miller LS (2014) 'Bias among Forensic Document Examiners: Still a Need for Procedural Changes', Australian Journal of Forensic Sciences 46(1), 91-7 
Strom KJ and Hickman MJ (2010) 'Unanalyzed Evidence in Law Enforcement Agencies: A National Examination of Forensic Processing in Police Departments', Criminology and Public Policy 9(2), 381-404

Suddendorf T and Corballis MC (2008) 'Episodic Memory and Mental Time Travel', Handbook of Behavioral Neuroscience 18, 31-42

Tangen JM, Thompson MB and McCarthy DJ (2011) 'Identifying Fingerprint Expertise', Psychological Science 22(8), 995-7

United States Department of Justice (1999) Eyewitness Evidence: A Guide for Law Enforcement, United States Department of Justice

Vincent F (2010) 'Vincent Report: Inquiry into the Circumstances that Led to the Conviction of Mr Farah Abdulkadir Jama’, Victorian Government Printer

Weathered L (2005) 'Pardon Me: Current Avenues for the Correction of Wrongful Conviction in Australia', Current Issues in Criminal Justice 17(2), 204-16

Weathered L (2012) ‘The Criminal Cases Review Commission: Considerations for Australia', Criminal Law Quarterly 58, 245-66

Weathered L (2013) 'Reviewing the New South Wales DNA Review Panel: Considerations for Australia', Current Issues in Criminal Justice 24, 449-58

Weisburd D and Neyroud P (2013) 'Police Science: Toward a New Paradigm', Australasian Policing 5(2), 13-21

Wells G, Small M, Penrod SD, Malpass R, Fulero S and Brimacombe C (1998) 'Eyewitness Identification Procedures: Recommendations for Lineups and Photospreads', Law and Human Behavior 22, 603-47

Westera NJ, Kebbell MR and Milne R (2011) ‘Interviewing Rape Complainants: Police Officers’ Perceptions of Interview Format and Quality of Evidence’, Applied Cognitive Psychology 25(6), 917-92

Wilcock R, Bull R and Milne B (2008) Witness Identification in Criminal Cases: Psychology and Practice, Oxford University Press

Williams R and Weetman J (2013) 'Enacting Forensics in Homicide Investigations', Policing and Society 23(3), 376-89 